University of Nebraska - Lincoln

DigitalCommons@University of Nebraska - Lincoln

June 2007

\title{
Using the Social Fabric Matrix to Analyze Institutional Rules Relative to Adequacy in Education Funding
}

Jerry L. Hoffman

Nebraska State Education Association and Nebraska Coalition for Educational Equity and Adequacy

F. Gregory Hayden

University of Nebraska - Lincoln, ghayden1@unl.edu

Follow this and additional works at: https://digitalcommons.unl.edu/cbafacpub

Part of the Business Commons

Hoffman, Jerry L. and Hayden, F. Gregory, "Using the Social Fabric Matrix to Analyze Institutional Rules Relative to Adequacy in Education Funding" (2007). College of Business Faculty Publications. 15.

https://digitalcommons.unl.edu/cbafacpub/15

This Article is brought to you for free and open access by the Business, College of at DigitalCommons@University of Nebraska - Lincoln. It has been accepted for inclusion in College of Business Faculty Publications by an authorized administrator of DigitalCommons@University of Nebraska - Lincoln. 


\title{
Using the Social Fabric Matrix to Analyze Institutional Rules Relative to Adequacy in Education Funding
}

\author{
Jerry L. Hoffman \\ and \\ F. Gregory Hayden
}

This article explains findings of part of a research project that uses the social fabric matrix (SFM) (Hayden 2006, 73-143) to analyze Nebraska's State education finance system with regard to adequacy and rules. The emphasis is about how to approach such a problem and to demonstrate the use of mathematical expressions to articulate social beliefs as instituted through rules, regulations, and requirements.

Concern for equity through equalization criteria has a long history in the analysis of state education systems. Concern for adequacy has become important in analysis recently, although court rulings indicate that it should have been of analytical importance earlier because most state constitutions call for an adequate education for all children. Nationally, since 1989, plaintiffs in 20 states have won school adequacy cases for additional funding in supreme courts. Defendant states have won seven. There are 12 cases pending, two of which are in Nebraska. The settlements require the state legislature to fix the constitutional deficiencies in the state funding formula. The Kansas Supreme Court, in summer 2006, ordered the legislature to expand its support to local school districts by doubling state spending on K-12 public education. The shift from equity to adequacy, in legal terms, moves the legal theory from equal protection claims to claims made on the education provisions of state constitutions. Constitutional terms such as "free instruction," "thorough and efficient education," "sound basic education," and "knowledge essential for good governance" have more interpretative meaning with regard to the "qualities" or "requirements" of schooling. Adequacy has support from the "standards-based" movement in that it considers a basket of goods, services, facilities, and technologies as the requirements necessary to deliver skills and knowledge to public school students (Rebell 2004, 40; and 2005, 291-324).

Jerry L. Hoffman is the Director of Higher Education Research, Nebraska State Education Association, and co-founder of Nebraska Coalition for Educational Equity and Adequacy. F. Gregory Hayden is a Professor of Economics, University of Nebraska-Lincoln. The authors wish to thank Tristan Markwell for econometric assistance. This paper was presented at the Annual Meeting of the Association for Evolutionary Economics, Chicago, IL, January 5-7, 2007. 
While the concept for adequacy in educational finance has become more refined and grounded in reality, the concept of rules in economics has become more abstract and divorced from reality. Articles about rules are often completed without one mention of real-world rules or an indication of how rules are related to institutions, technology, and ecological systems. Much of the rule literature is becoming a case of layering abstraction upon abstraction without validation by recurrence to reality. Yet, for rule concepts to be about reality, they need to be actualized in real situations of particular time and space (Dopfer 2006, 4). In that way, abstractions can be enriched to be conceptually valid. To assist in enriching rule concepts, we identify and model social agents that make the rules, the organizational subjects that apply the rules, and the object rules associated with the organizations (see Dopfer 2006, 32).

Figure 1 is a reduced version of the larger project's SFM. The first six rows are a list of the normative belief criteria that influence institutional organizations, as indicated by the ones in the first six rows for columns 7 and 8 . In turn, those same organizations in rows 7 and 8 deliver rules in the form of court decisions and laws to the organizations represented in columns 9 through 13. (The term rules will be used here as shorthand for rules, regulations, and requirements.) Our interest is with the deliveries in cells $(7,12),(8,12),(8,13)$, and $(13,12)$. Together these cells contain the State education finance system called Tax Equity and Educational Opportunities Support Act (TEEOSA). Different calculations for different parts of TEEOSA are made by different agencies and niches within agencies, and from many different databases and computer programs. A mathematical formula of the whole set of TEEOSA rules and their calculations has not existed until finalized for this project.

The relevant SFM digraph and TEEOSA sub-model are demonstrated with the digraph created by the program ithink in Figure 2. Connected to each element in the sub-model is the ithink calculation process that contains the formula terms (1) through (9), as explained next.

\section{Tax Equity and Educational Opportunities Support Act Formula Terms}

As the TEEOSA process is brought together, each school district might be thought of as being on an assembly line. As each district moves from left to right in Figure 2, the rules specified in Nebraska laws determine what happens to the district. Different kinds of school districts are treated differently with regard to student count, finance, cost factors, demographics, and so forth. The importance of rules becomes obvious when TEEOSA begins to manufacture the number of students for the districts.

\section{Generating Students, Cost, and Expenditure Growth Factors}

Fall Membership: The fall membership is the number of students enrolled in each grade category for the year prior (y1) to the fall semester of the year for which state aid is being calculated. The left side of Figure 2 designates the fall membership (FM) for 
Figure 1. Social Fabric Matrix for Nebraska State Funding for K-12 Public Schools

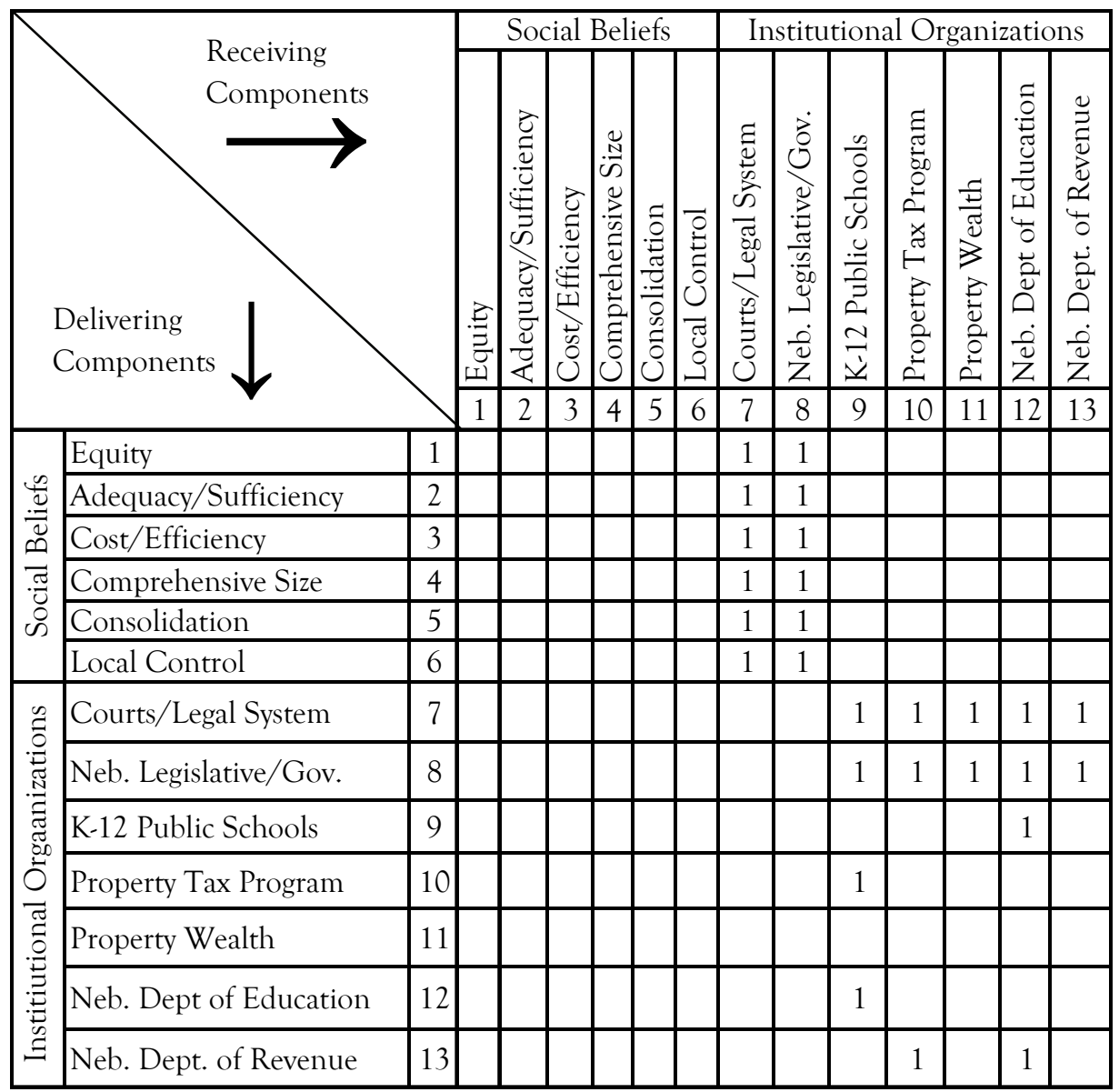

grade-range categories as follows: one-half day kindergarten (Ky1), full-day kindergarten through grade six (FDSKy1), grades seven and eight (SEy1), and grades nine through twelve (NTy1) (Neb. Rev. Stat. § 79-1003(16), Supp. 2005).

Adjusted Fall Membership Formula Students: Term (1) expresses the way that the FM categories are adjusted to find what Nebraska law defines as formula students (FS).

$\left[333\left(\frac{\mathrm{ADM}_{\mathrm{y} 2}}{\mathrm{FM}_{\mathrm{y} 2}}+\frac{\mathrm{ADM}_{\mathrm{y} 3}}{\mathrm{FM}_{\mathrm{y} 3}}+\frac{\mathrm{ADM}_{\mathrm{y} 4}}{\mathrm{FM}_{\mathrm{y} 4}}\right)\left(\mathrm{K}_{\mathrm{y} 1}+\mathrm{FDKS}_{\mathrm{y} 1}+\mathrm{SE}_{\mathrm{y} 1}+\mathrm{NT}_{\mathrm{y} 1}\right)\right]$

$+\left(\mathrm{KC}_{\mathrm{y} 1}+\mathrm{FDKC}_{\mathrm{y} 1}+\mathrm{SEC}_{\mathrm{y} 1}+\mathrm{NTC}_{\mathrm{y} 1}\right)$ 
Figure 2. Calculation of Nebraska State K-12 Funding Formula Using ithink Sub-Model
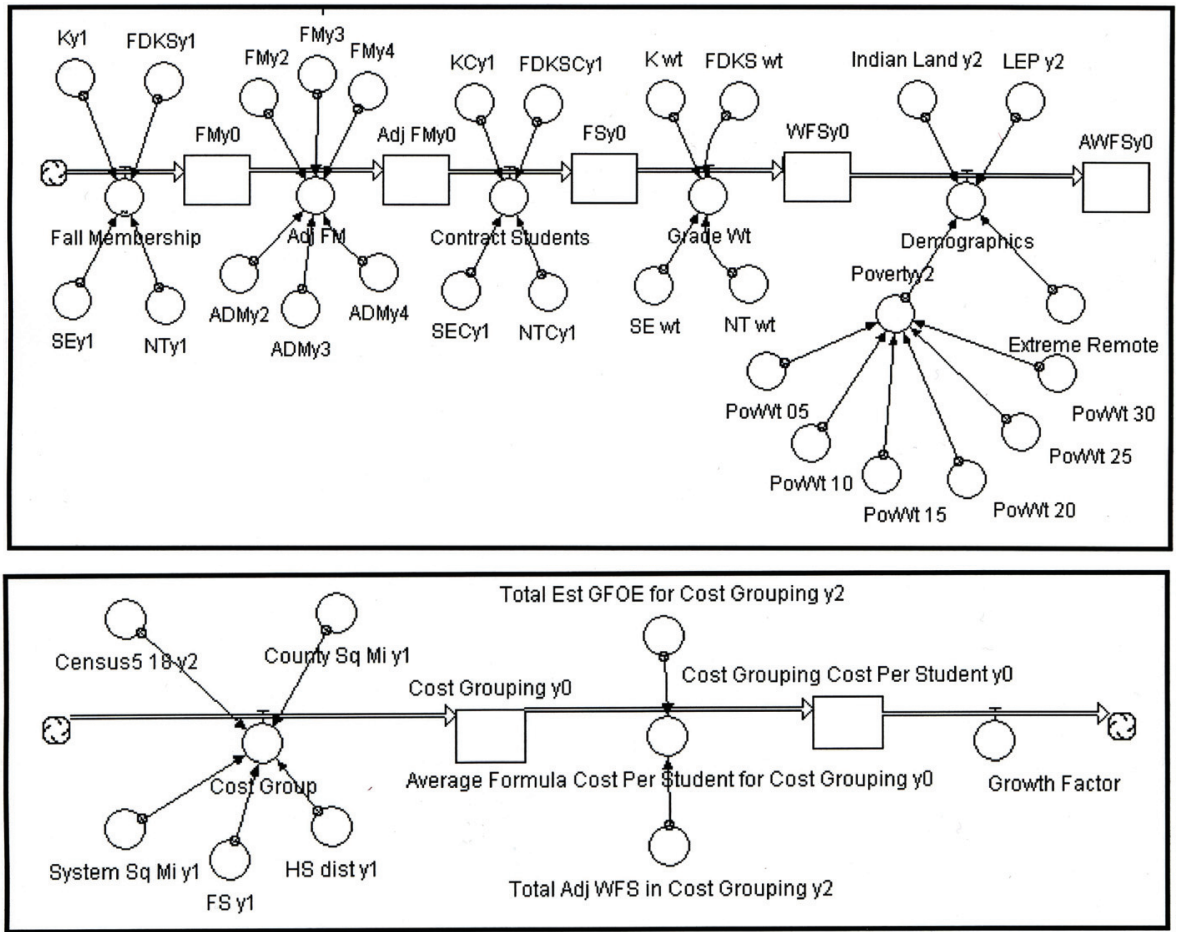

In term (1), each of the grade categories is multiplied by the average ratio of the year's average daily membership (ADM) divided by the FM for the second (y2), third (y3), and fourth ( $\mathrm{y} 4)$ years prior to the formula year $(\mathrm{y} 0)$. To this product is added the number of students that the school district contracts out to other districts for the respective grade levels for the prior year, as indicated by Contract Students in Figure 2. Students contracted out for the different grades are one-half day kindergarten (KCy1), full-day kindergarten through grade six (FDKSCy1), grades seven and eight (SECy1), and grades nine through twelve (NTCy1). This rule specifies how the number of FS is to be generated (Neb. Rev. Stat. § 79-1003(18), Supp. 2005). It is utilized in different terms of the Nebraska State school aid formula.

Weighted Formula Students: Weighted formula students (WFSyO in Figure 2) are calculated by multiplying the grade categories in the FS formula in term (1) times the coefficients designated by law for weighting the different grade categories. The grade weighting coefficients (Grade Wt in Figure 2) are .5 for one-half day kindergarten, 1.00 for full-day kindergarten through grade six, 1.2 for grades seven and eight, and 1.4 for grades nine through twelve (Neb. Rev. Stat. § 79-1007.01(1)(ab), Supp. 2005). Thus, the WFS formula term is as follows: 
$\left[.333\left(\frac{\mathrm{ADM}_{\mathrm{y} 2}}{\mathrm{FM}_{\mathrm{y} 2}}+\frac{\mathrm{ADM}_{\mathrm{y} 3}}{\mathrm{FM}_{\mathrm{y}} 3}+\frac{\mathrm{ADM}_{\mathrm{y}} 4}{\mathrm{FM}_{\mathrm{y}} 4}\right)\left(.5 \mathrm{~K}_{\mathrm{y} 1}+\mathrm{FDKS}_{\mathrm{y} 1}+1.2 \mathrm{SE}_{\mathrm{y} 1}+1.4 \mathrm{NT}_{\mathrm{y} 1}\right)\right]$

$+\left(.5 \mathrm{KC}_{\mathrm{y}} 1+\mathrm{FDKC}_{\mathrm{y}} 1+1.2 \mathrm{SEC}_{\mathrm{y} 1}+1.4 \mathrm{NTC} 1\right)$

Adjusted Weighted Formula Students: A set of demographic factors (Demographics in Figure 2) are added to the WFS term to find the adjusted weighted formula students (AWFS).

The first is the Indian-land factor which is the average daily attendance (ADA) of prior-year students who reside on what is designated as Indian land multiplied by .25 (Neb. Rev. Stat. § 79-1003(c)(i), Supp. 2005), or:

$.25($ IndianLandADAy1)

The second is the number in the year prior to the formula year of students in the local system with limited English proficiency (LEPy-1) multiplied by .25 (Neb. Rev. Stat. § 79-1003(c)(ii), Supp. 2005), or:

$.25(\mathrm{LEPy} 1)$

The third is the extreme-remoteness factor, which provides that if a school district has 1) less than 200 formula students, 2) more than 600 miles in the district, 3) less than .3 formula students per square mile in the district, and 4) more than 25 miles between high school attendance centers; the district is to be credited with an additional .125 students for each FS as term (1) calculated (Neb. Rev. Stat. § 79-1003 (c)(iv), Supp. 2005), or:

$.125\left\{\left[.333\left(\frac{\mathrm{ADM}_{\mathrm{y} 2}}{\mathrm{FM}_{\mathrm{y} 2}}+\frac{\mathrm{ADM}_{\mathrm{y} 3}}{\mathrm{FM}_{\mathrm{y} 3}}+\frac{\mathrm{ADM}_{\mathrm{y} 4}}{\mathrm{FM}_{\mathrm{y} 4}}\right)\left(\mathrm{K}_{\mathrm{y} 1}+\mathrm{FDKS}_{\mathrm{y} 1}+\mathrm{SE}_{\mathrm{y} 1}+\mathrm{NT}_{\mathrm{y} 1}\right)\right]\right.$
$\left.+\left(\mathrm{KC}_{\mathrm{y} 1}+\mathrm{FDKS}_{\mathrm{y} 1}+\mathrm{SEC}_{\mathrm{y} 1}+\mathrm{NTC}_{\mathrm{y} 1}\right)\right\}$

The fourth demographic factor is the poverty factor. In addition to lowincome students (LI) being counted in formula terms above, additional students are added to a school district's total according to the poverty factor. To calculate the poverty factor, the number of LI students is utilized as determined by the number of LI in the district reported by the Nebraska Department of Revenue (SFM cell 13,12) or by the FS qualified for free lunch or free milk (SFM cell 9,12) whichever is greater. The LI number is then decreased. The number of LI students in the district must be 5 percent or greater than the total number of FS (term (1) above) in the school for any additional students to be added because of LI students. The function to calculate 
the poverty factor is then weighted to increase at an increasing rate as additional percentage points above 5 percent are added, with the rate of increase changing with each additional 5 percent of FS. For example, if the number of LI students is from 5 to 10 ten percent of FS, the percent LI is of FS is multiplied by 5 percent; if that percent is between 10 and 15 percent, it is multiplied by 10 percent, and so forth (Neb. Rev. Stat. § 79-1003(c)(iii)(A-G), Supp. 2005). The formula term utilized here for the poverty factor utilizes the delta method to specify how to calculate the number of students to be added to a school district's student count, as follows:

$$
\begin{aligned}
& \langle .05 \mathrm{LI}[\delta(.05)+\delta(.10)+\delta(.15)+\delta(.20)+\delta(.25)+\delta(.30)] \\
& -.05^{2}\left[.333\left(\frac{\mathrm{ADM}_{\mathrm{y} 2}}{\mathrm{FM}_{\mathrm{y} 2}}+\frac{\mathrm{ADM}_{\mathrm{y} 3}}{\mathrm{FM}_{\mathrm{y} 3}}+\frac{\mathrm{ADM}_{\mathrm{y} 4}}{\mathrm{FM}_{\mathrm{y} 4}}\right)\left(\mathrm{K}_{\mathrm{y} 1}+\mathrm{FDKS}_{\mathrm{y} 1}+\mathrm{SE}_{\mathrm{y} 1}+\mathrm{NT}_{\mathrm{y} 1}\right)\right. \\
& \left.+\left(\mathrm{KC}_{\mathrm{y} 1}+\mathrm{FDKSC}_{\mathrm{y} 1}+\mathrm{SEC}_{\mathrm{y} 1}+\mathrm{NTC}_{\mathrm{y} 1}\right)\right]
\end{aligned}
$$

$[\delta(.05)+2 \delta(.10)+3 \delta(.15)+4 \delta(.20)+5 \delta(.25)+6 \delta(.30)]) ;$ where $\delta(\mathrm{C})=\left\{\begin{array}{l}1, \frac{\mathrm{LI}}{\mathrm{FS}} \geq \mathrm{C} \\ 0, \text { else }\end{array}\right.$

Delta and its correspondent variable $(\mathrm{C})$ are combined as a function (not to indicate that they are multiplied). Examples of $\mathrm{C}$ with $\delta$ are $\delta(.05)$ and $\delta(.30)$. The conditions define that a function such as $\delta(.15)$ is 1 or 0 depending on the ratio of LI/FS. Functions less than LI/FS are 1 and those greater than LI/FS are 0 .

Terms (2) through (6) are added together to generate a district's adjusted weighted formula students (AWFS) (Neb. Rev. Stat. § 79-1007.01(2)(a-b), Supp. 2005). This result is multiplied times the average operating cost per student, as explained next with formula terms (7), (8), and (9).

Cost Grouping: State laws divide the school districts in Nebraska into three different cost groupings. Those groupings are 1) very sparse, 2) sparse, and 3) standard; and, as their names imply, these groupings are related to the geographical density of students in the district. As expressed in Figure 2, the geographical density is determined by 1) census of students per square mile in the county, 2) FS per square mile in the school district, and 3) miles between high schools. Operating cost information provided by the districts in the different cost groups (cell 9,12) is used to make calculations for all the districts in their respective groups.

Cost Grouping Cost Per Student: For each cost grouping, the districts' estimated General Fund Operation Expenditures (GFOE) are summed for all the districts in the grouping. Term (7) below sums the General Fund Operating Expenditures (GFOE) for all school districts, as adjusted (Neb. Rev. Stat. § 79-007.02 (1)(a-c), Supp. 2005). The cost-grouping sum with adjustments is represented as follows:

$\sum_{i=1}^{n}\left[\mathrm{GFOE}_{\mathrm{y} 2}\right.$; which includes $(\mathrm{TP}+\mathrm{SS}+\mathrm{AE}+\mathrm{TfOF}+\mathrm{CS}+\mathrm{GFDSP}+\mathrm{TransPd}+\mathrm{StCat}$

$\left.+\mathrm{RIP}+\mathrm{SDA})_{\mathrm{y} 2}-(\mathrm{TP}+\mathrm{SS}+\mathrm{AE}+\mathrm{TfOF}+\mathrm{CS}+\mathrm{GFDSP}+\mathrm{TransPd}+\mathrm{StCat}+\mathrm{RIP}+\mathrm{SDA})_{\mathrm{y} 2}\right]$ 
Each district's GFOE for the most recently available complete data year (usually y2) is adjusted by a series of expenditures that are included and then subtracted. Those expenditure items are tuition paid (TP), summer school (SS), adult education (AE), transfers from other funds (TfOF), community services (CS), redemption of general fund debt service principal (GFDSP), transportation paid to other districts (TransPD), State categorical programs (StCat), retirement incentive program (RIP), and staff development assistance (SDA). Term (7) is divided by term (8) (Nebraska Department of Education 2006).

Term (8) is the sum of the total weighted formula students for terms (2), (3), (4), (5), and (6) for all school districts in the State, expressed simply as:

Sum of terms $(2)+(3)+(4)+(5)+(6)$ for districts 1 through $n$

When terms (2) through (6) are summed for all districts, term (8) determines the total number of students generated in Nebraska eligible for aid. Term (7) divided by term (8) provides a kind of average expenditure per child to be applied for every district in a cost grouping. It is referred to as the average formula cost per student for the cost grouping. This is multiplied times a cost-growth factor. The growth factor is found with term (9) defined as follows:

$$
\begin{aligned}
& \left\{1+\llbracket 2\left\langle\sum _ { i = 1 } ^ { n } \left\{\left[.333\left(\frac{\mathrm{ADM}_{\mathrm{y} 2}}{\mathrm{FM}_{\mathrm{y} 2}}+\frac{\mathrm{ADM}_{\mathrm{y} 3}}{\mathrm{FM}_{\mathrm{y} 3}}+\frac{\mathrm{ADM}_{\mathrm{y} 4}}{\mathrm{FM}_{\mathrm{y} 4}}\right)\left(\mathrm{K}_{\mathrm{y} 1}+\mathrm{FDSK}_{\mathrm{y} 1}+\mathrm{SE}_{\mathrm{y} 1}+\mathrm{NT}_{\mathrm{y} 1}\right)\right]\right.\right.\right. \\
& +\left(\mathrm{KC}_{\mathrm{y} 1}+\mathrm{FDKC}_{\mathrm{y} 1}+\mathrm{SEC}_{\mathrm{y} 1}+\mathrm{NTC}_{\mathrm{y} 1}\right) \\
& \left.-\left(\mathrm{ADM}_{\mathrm{y} 2}+\mathrm{TS}_{\mathrm{y} 2}\right)\right\} /\left\{\sum_{i=1}^{n}\left[\mathrm{ADM}_{\mathrm{y} 2}+\mathrm{TS}_{\mathrm{y} 2}\right]\right\} ; \text { only if }>0 \\
& \left.\left.+\left[\mathrm{BARG}_{\mathrm{yo}}+\mathrm{BARG}_{\mathrm{y} 1}+\mathrm{SBG}_{\mathrm{yo}}+.5\left(\mathrm{SGB}_{\mathrm{y} 1}\right)\right]\right\rangle\right\}
\end{aligned}
$$

Term (9) sums the remainder of FS minus the total of the ADM plus the tuition students (TS) for all the districts in Nebraska. That sum is divided by the sum of the ADM plus the TS for all the districts (Neb. Rev. Stat. § 79.1007.02(2)(a), Supp. 2005). That dividend, if it is greater than zero, is added to the sum of the following growth rates: 1) the basic allowable growth rate for the expenditure for individual school districts for the formula year (BAGRy0), plus 2) the basic allowable growth rate for the prior year (BAGRy1), plus 3) the growth rate allowed by special action of school boards for the formula year (SBGy0), plus 4) 50 percent of growth rate allowed by special action of school boards for the prior year (.50SBGy1) (Neb. Rev. Stat. § 79.1007.02(2)(b), Supp. 2005; Neb. Rev. Stat. § 79.1025, Reissue 2004; Neb. Stat. § 77-3446, Reissue Rev. Stat. 2004). That sum is multiplied by two and the resulting 
product is added to 1 , as shown in term (9). In turn, term (9) is multiplied by the dividend of term (7) divided by term (8).

\section{School District Need}

The product of the dividend of term (7) divided by term (8) times term (9) is utilized to calculate what is called district need. This is done by multiplying that product times the sum of terms (2) through (6) for each district to determine each district's State need for aid from this part of the formula. Furthermore, terms (1) through (9) provide important components that are utilized throughout the longer State education finance formula.

\section{Concluding Observations}

This paper is part of a larger effort to use the SFM and ithink program to model process flows and deliveries of the current Nebraska school funding system. The effort is aimed at developing a series of new state policies that construct a new funding model guided by social beliefs of equity and adequacy and based on instrumental scientific methods of measuring the actual costs of educational goods, services, and technologies needed in public school classrooms. The research is guided by the court decisions favoring adequacy. As is apparent from the articulation above, terms (1) through (9) are not structured to provide for adequacy.

The set of laws represented in the formula terms is often referred to as concerned with identifying need. What the terms mainly represent is an average of past expenditures of all districts multiplied by a growth rate. It is not need in general that is being projected, and it is not the expenditure needed to provide for adequacy. While the so-called need portion of the formula includes past expenditures for teachers, for example, there is nothing in the formula to address the specifics of or funding needed for a sufficient cadre of qualified teachers. The formula is excessively complex and arbitrary. Neither particular inputs nor expenditure levels are specified in order to provide an adequate education. The accumulation of school funding rules uses historic student cost rather than indicators of need. The weighting coefficients in terms (2) and (6) are without substantive foundation, and the growth factors in term (8) are arbitrary.

Two conceptual observations about rules and beliefs are apparent from the study. First, from the national experience, we see that rules being enforced to structure various states' school finance systems are socially deviant and therefore arbitrary, because the courts have found them to be inconsistent with the social beliefs expressed in state constitutions. This finding is inconsistent with the rules literature in which the assumption is made that applied rules are an expression of social norms. Yet, they often are not. There is a whole array of reasons that can make rules deviate from belief norms. The reasons include: 1 ) a wide disparity in political and economic power so that powerful interests can institute rules to deprive others; 2) an ideology that emphasizes the application of a narrow set of criteria to the exclusion of other 
relevant criteria; and 3) legislators and governors who are ignorant of the need to discover and specify beliefs and structure rules to fit those beliefs.

Second, in completing the SFM and ithink sub-model in this study, we found that beliefs do not deliver directly to other beliefs, rules do not deliver directly to other rules, and beliefs and rules do not deliver directly to each other. Influences among these components are delivered through the activities of institutional organizations. Although that finding has been presented conceptually (Hayden 1998), in the social science literature reviewed, it has not been confirmed by other applied studies. Additional studies in other settings will be necessary before it can be validated as a general theoretical proposition. However, in the meantime, researchers should be cautious about entries in SFM cells with belief-belief, rule-rule, and belief-rule deliveries. We have not found them to exist in this real-world setting.

\section{References}

Dopfer, Kurt. "The Origins of Meso Economics: Schumpeter's Legacy." In Papers on Economics and Evolution, edited by Evolutionary Economics Group, 1-44. Jena, Germany: Max Planck Institute of Economics, 2006.

Hayden, F. Gregory. "Normative Analysis of Instituted Processes." In Institutionalist Theory and Applications, edited by Sason Fayazmanesh and Marc R. Tool, 89-107. North Hampton, MA: Edward Elgar Publishing, Inc., 1998.

—. Policymaking for a Good Society: The Social Fabric Matrix Approach to Policy Analysis and Program Evaluation. New York: Springer, 2006.

Justia US Laws. Nebraska Chapter 79-Schools. http://law.justia.com/nebraska/codes/s79index.html (accessed August 18, 2006).

Nebraska Department of Education. Annual Financial Report of Nebraska School Districts, 2005-06AFR. http://ess.nde.state.ne.us/SchoolFinance/AFR/ Downloads/0506/0506afr.xls (accessed August 15, 2006).

Rebell, Michael A. "Why Adequacy Lawsuits Matters." Education Week 23, 3 (2004): 40.

"Adequacy Litigation: A New Path to Equity?" In Bringing Equity Back: Research for a New Era in American Educational Policy, edited by Janice Petrovich and Amy Stuart Wells, 291-324. New York: Teachers College Press, 2005. 